\title{
Comment on Costa et al. The Effectiveness of Different Concepts of Bracing in Adolescent Idiopathic Scoliosis (AIS): A Systematic Review and Meta-Analysis. J. Clin. Med. 2021, 10,2145
}

\section{Hans-Rudolf Weiss}

check for

Citation: Weiss, H.-R. Comment on Costa et al. The Effectiveness of Different Concepts of Bracing in Adolescent Idiopathic Scoliosis (AIS): A Systematic Review and Meta-Analysis. J. Clin. Med. 2021, 10, 2145. J. Clin. Med. 2022, 11, 752. https://doi.org/10.3390/ jcm11030752

Academic Editor: Theodoros B. Grivas

Received: 28 October 2021 Accepted: 27 January 2022 Published: 30 January 2022

Publisher's Note: MDPI stays neutral with regard to jurisdictional claims in published maps and institutional affiliations.

Copyright: (C) 2022 by the author. Licensee MDPI, Basel, Switzerland. This article is an open access article distributed under the terms and conditions of the Creative Commons Attribution (CC BY) license (https:// creativecommons.org/licenses/by/ $4.0 /)$.
Schroth Best Practice Academy, 55546 Neu-Bamberg, Germany; hr.weiss@koob-skoliose.com

I read the above-mentioned work with great interest, and I would like to thank the authors for considering two papers from our working group. However, I wonder why our paper containing the preliminary results of the treatment with the Gensingen Brace [1] was taken into account within this systematic review but not the final results that were first published online in 2020 [2]. The latter paper with the final results would have had a lower risk of bias than the paper containing the preliminary results.

The authors seem committed to finding the most effective concept of bracing or even the most effective brace model. In my opinion, however, they have chosen the wrong study design for this because one cannot find this through averaging and can only find it through an individual case analysis.

Surprisingly, in their systematic review regarding night-time brace treatment, the authors came to completely different conclusions than the authors of another current systematic review on the subject [3]. Ruffilli et al. [3] concluded that "the current available literature does not permit us to draw conclusions about night-time braces. The low methodological quality of the studies examined makes it impossible to compare the effectiveness of the night-time braces with that of traditional TLSOs".

In fact, the results of night-time bracing are very diverse. As early as 1997, there was a meta-analysis that showed that part-time or night bracing was clearly inferior to full-time brace treatment [4]. Further studies on this topic clearly show that wearing time and the correction effect are the two main criteria for success $[5,6]$. The greater the corrective effect of a brace and the longer the wearing time, the greater the success rate $[5,6]$. However, the authors do not discuss these important parameters in their study.

The question is how the authors of this systematic review, compared to Ruffilli et al. [3], came to such different conclusions:

One study on the Providence Brace included by the authors has an exceptionally high success rate [7], while other studies on the Providence Brace tend to conclude with success rates of between $50 \%$ and $60 \%$ [8]. One study cited by the authors has a success rate of over $70 \%$, but this is a more mature and therefore prognostically more favorable cohort (Risser 0-3) [9].

A success rate of $89 \%$ in a night-time brace is very exceptional [7]. However, if one reads the study carefully, one will find the following passage on the subject of inclusion criteria: "We included all patients, diagnosed with AIS who fulfilled the following criteria, age $>10$ years at time of diagnosis, less than 12 months post-menarche, Cobb $20^{\circ}-42^{\circ}$, no prior scoliosis treatment, initial in-brace curve correction $>60 \%$ and follow-up including radiographs at least 12 months after brace termination. The patients were braced according to the SRS criteria".

Accordingly, this study [7] is a selective study with favorable inclusion criteria. No statement can be found in the paper on the outcome of the patients with a correction effect of $<60^{\circ}$. Interestingly, this particular patient selection is addressed neither in the abstract nor further elaborated in the discussion. In addition, the collective of Simony et al. [7] also failed to meet the SRS inclusion criteria for brace studies. The Risser sign, as an essential 
part of the SRS inclusion criteria, was not recorded, and the cohort was also significantly older than in comparable studies on the topic [1,2]. This was-among other things-already discussed in a letter to the editor by Dr. Potts [10].

The problem was thus known, and yet, this work with a considerable selection bias [7] was included by the authors in their systematic review with meta-analysis and was related to other studies without correspondingly favorable patient selection. This systematic review with meta-analysis by Costa et al., therefore, has a systematic selection bias and should not have been published in the present form. This all too positive outlier with a success rate of $89 \%$ [7] has a significant influence on the results of this review. Without the inclusion of the Simony paper [7], one would not come to the conclusion that the results of night-time bracing are on a par with full-time bracing.

Finally, the authors did not indicate a conflict of interest (René M. Castelein, Stryker Spine (a, d), found in the programs of the SRS Conferences 2020 and 2021, [11,12]).

The fact that publications contaminated by errors coexist with their healthy counterparts in different databases, and in the worst-case scenario, multiply in systematic reviews and meta-analyses, is well recognized [13]. And this is just what has happened in the paper addressed within this comment.

\section{Conclusions}

1. The goal of finding the most effective bracing concept or even the most effective brace model was not achieved and was not further discussed in this work.

2. The unveiled findings cannot be reconciled with the study design of a systematic review with meta-analysis. The study shows features of a narrative review with a pronounced selection bias, which significantly influences the conclusions.

3. The fact that the described original work with a considerable selection bias [7] was included by the authors in their so-called systematic review with meta-analysis despite extensive discussion in the literature [9] raises doubts about a simple oversight as the cause.

Funding: This research received no external funding.

Institutional Review Board Statement: Not applicable.

Informed Consent Statement: Not applicable.

Data Availability Statement: Not applicable.

Conflicts of Interest: The author currently serves as the senior consultant for Koob Scolitech GmbH, Neu-Bamberg, Germany. The company is held by the spouse of the author. He has held a patent on a sagittal realignment brace (EP 1604624 A1).

\section{References}

1. Weiss, H.R.; Tournavitis, N.; Seibel, S.; Kleban, A. A Prospective Cohort Study of AIS Patients with $40^{\circ}$ and More Treated with a Gensingen Brace (GBW): Preliminary Results. Open Orthop. J. 2017, 11, 1558-1567. [CrossRef] [PubMed]

2. Weiss, H.R.; Lay, M.; Seibel, S.; Kleban, A. Is it possible to improve treatment safety in the brace treatment of scoliosis patients by using standardized CAD algorithms? Orthopäde 2021, 50, 435-445. (In German) [CrossRef] [PubMed]

3. Ruffilli, A.; Fiore, M.; Barile, F.; Pasini, S.; Faldini, C. Evaluation of night-time bracing efficacy in the treatment of adolescent idiopathic scoliosis: A systematic review. Spine Deform. 2021, 9, 671-678. [CrossRef] [PubMed]

4. Rowe, D.E.; Bernstein, S.M.; Riddick, M.F.; Adler, F.; Emans, J.B.; Gardner-Bonneau, D. A meta-analysis of the efficacy of non-operative treatments for idiopathic scoliosis. J. Bone Joint Surg. Am. 1997, 79, 664-674. [CrossRef] [PubMed]

5. Landauer, F.; Wimmer, C.; Behensky, H. Estimating the final outcome of brace treatment for idiopathic thoracic scoliosis at 6-month follow-up. Pediatr. Rehabil. 2003, 6, 201-207. [CrossRef] [PubMed]

6. $\quad$ van den Bogaart, M.; van Royen, B.J.; Haanstra, T.M.; de Kleuver, M.; Faraj, S.S.A. Predictive factors for brace treatment outcome in adolescent idiopathic scoliosis: A best-evidence synthesis. Eur. Spine J. 2019, 28, 511-525. [CrossRef] [PubMed]

7. Simony, A.; Beuschau, I.; Quisth, L.; Jespersen, S.M.; Carreon, L.Y.; Andersen, M.O. Providence nighttime bracing is effective in treatment for adolescent idiopathic scoliosis even in curves larger than 35 . Eur. Spine J. 2019, 28, 2020-2024. [CrossRef] [PubMed] 
8. Davis, L.; Murphy, J.S.; Shaw, K.A.; Cash, K.; Devito, D.P.; Schmitz, M.L. Nighttime bracing with the Providence thoracolumbosacral orthosis for treatment of adolescent idiopathic scoliosis: A retrospective consecutive clinical series. Prosthet. Orthot. Int. 2019, 43, 158-162. [CrossRef] [PubMed]

9. Yrjönen, T.; Ylikoski, M.; Schlenzka, D.; Kinnunen, R.; Poussa, M. Effectiveness of the Providence nighttime bracing in adolescent idiopathic scoliosis: A comparative study of 36 female patients. Eur. Spine J. 2006, 15, 1139-1143. [CrossRef] [PubMed]

10. Potts, M.A. Letter to the editor concerning "Providence nighttime bracing is effective in treatment for adolescent idiopathic scoliosis even in curves larger than $35^{\circ}$ " by Simony A, Beuschau I, Quisth L, et al. (Eur Spine J; [2019]:. https://doi.org/10.1007/s00586019-06077-z). Eur. Spine J. 2020, 29, 641-642. [CrossRef] [PubMed]

11. Scoliosis Research Society Virtual 55th Annual Meeting. p. 17. Available online: https://www.srs.org/UserFiles/file/AM20FinalProgram.pdf (accessed on 3 December 2021).

12. Scoliosis Research Society 56th Annual Meeting 22-25 September 2021, St. Louis, MI, USA. p. 29. Available online: https: //www.srs.org/UserFiles / file/AM21_FinalProgram.pdf (accessed on 3 December 2021).

13. Stamm, T. From honest mistakes to fake news-Approaches to correcting the scientific literature. Head Face Med. 2020, 16, 6. [CrossRef] [PubMed] 